\title{
The fate of $\mathrm{N}_{2} \mathrm{O}$ consumed in soils
}

\author{
B. Vieten, F. Conen, B. Seth, and C. Alewell \\ Institute of Environmental Geosciences, University of Basel, Bernoullistrasse 30, 4056 Basel, Switzerland
}

Received: 8 August 2007 - Published in Biogeosciences Discuss.: 24 September 2007

Revised: 17 December 2007 - Accepted: 5 January 2008 - Published: 1 February 2008

\begin{abstract}
Soils are capable to consume $\mathrm{N}_{2} \mathrm{O}$. It is generally assumed that consumption occurs exclusively via respiratory reduction to $\mathrm{N}_{2}$ by denitrifying organisms (i.e. complete denitrification). Yet, we are not aware of any verification of this assumption. Some $\mathrm{N}_{2} \mathrm{O}$ may be assimilatorily reduced to $\mathrm{NH}_{3}$. Reduction of $\mathrm{N}_{2} \mathrm{O}$ to $\mathrm{NH}_{3}$ is thermodynamically advantageous compared to the reduction of $\mathrm{N}_{2}$. Is this an ecologically relevant process? To find out, we treated four contrasting soil samples in a flow-through incubation experiment with a mixture of labelled $(98 \%){ }^{15} \mathrm{~N}_{2} \mathrm{O}(0.5-4 \mathrm{ppm})$ and $\mathrm{O}_{2}$ $(0.2-0.4 \%)$ in He. We measured $\mathrm{N}_{2} \mathrm{O}$ consumption by GCECD continuously and $\delta^{15} \mathrm{~N}$ of soil organic matter before and after an 11 to 29 day incubation period. Any ${ }^{15} \mathrm{~N}_{2} \mathrm{O}$ assimilatorily reduced would have resulted in the enrichment of soil organic matter with ${ }^{15} \mathrm{~N}$, whereas dissimilatorily reduced ${ }^{15} \mathrm{~N}_{2} \mathrm{O}$ would not have left a trace. None of the soils showed a change in $\delta^{15} \mathrm{~N}$ that was statistically different from zero. A maximum of $0.27 \%$ (s.e. $\pm 0.19 \%$ ) of consumed ${ }^{15} \mathrm{~N}_{2} \mathrm{O}$ may have been retained as ${ }^{15} \mathrm{~N}$ in soil organic matter in one sample. On average, ${ }^{15} \mathrm{~N}$ enrichment of soil organic matter during the incubation may have corresponded to a retention of $0.019 \%$ (s.e. $\pm 0.14 \% ; n=4$ ) of the ${ }^{15} \mathrm{~N}_{2} \mathrm{O}$ consumed by the soils. We conclude that assimilatory reduction of $\mathrm{N}_{2} \mathrm{O}$ plays, if at all, only a negligible role in the consumption of $\mathrm{N}_{2} \mathrm{O}$ in soils.
\end{abstract}

\section{Introduction}

Nitrous oxide $\left(\mathrm{N}_{2} \mathrm{O}\right)$ is produced in soils during the processes of nitrification and denitrification (Firestone et al., 1980). Since industrialisation, the global atmospheric $\mathrm{N}_{2} \mathrm{O}$ concentration increased from about $270 \mathrm{ppb}$ in 1800 to $319 \mathrm{ppb}$ in

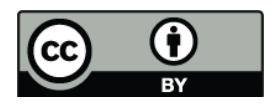

Correspondence to: B. Vieten

(b.vieten@unibas.ch)
2005 (IPCC, 2006). Currently, more than one third of all $\mathrm{N}_{2} \mathrm{O}$ emissions are of anthropogenic origin and primarily due to agriculture (IPCC, 2006). However, soils can also act as a sink for $\mathrm{N}_{2} \mathrm{O}$ (reviewed in Chapuis-Lardy et al., 2007). In general, it is implicitly assumed that complete denitrification (reduction of $\mathrm{N}_{2} \mathrm{O}$ to $\mathrm{N}_{2}$ ) is the only process responsible for observed sink activity. Once produced by a soil organism, a molecule of $\mathrm{N}_{2} \mathrm{O}$ is presumed to take one of the three known routes (Ostrom et al., 2007) (Fig. 1): (1) complete denitrification to $\mathrm{N}_{2}$ within the cell prior to its escape into the gas phase (reviewed in Zumft, 1997); (2) escape from the cell into the gas phase of soil and potentially to the atmosphere; or (3) complete denitrification to $\mathrm{N}_{2}$ upon re-entering a cell capable to reduce $\mathrm{N}_{2} \mathrm{O}$ (e.g. Neftel et al., 2000; Clough et al., 2005). To the best of our knowledge other pathways have not been considered in natural soil so far. Here, we hypothesise a fourth pathway of assimilatory reduction to $\mathrm{NH}_{3}$ may be responsible for some of observed $\mathrm{N}_{2} \mathrm{O}$ consumption in soil (Fig. 1).

The only enzyme known to reduce $\mathrm{N}_{2} \mathrm{O}$ to $\mathrm{NH}_{3}$ is nitrogenase. First evidence was provided by Mozen and Burris (1954). Later studies confirmed that $\mathrm{N}_{2} \mathrm{O}$ can be a substrate for nitrogenase which reduces $\mathrm{N}_{2} \mathrm{O}$ to $\mathrm{N}_{2}$ with subsequent reduction of $\mathrm{N}_{2}$ to $\mathrm{NH}_{3}$ (Hoch et al., 1960; Hardy and Knight, 1966; Jensen and Burris, 1986). However, one year later, reduction of $\mathrm{N}_{2} \mathrm{O}$ to $\mathrm{N}_{2}$ was already questioned by Yamazaki et al. (1987). They concluded from the stable isotope kinetics during $\mathrm{N}_{2} \mathrm{O}$ fixation by Azotobacter vinelandii that $\mathrm{N}_{2} \mathrm{O}$ fixation by nitrogenase must be an apparent one-step reaction transforming $\mathrm{N}_{2} \mathrm{O}$ directly into $\mathrm{NH}_{3}$, without the intermediary $\mathrm{N}_{2}$. This conclusion was supported by a re-interpretation of the original results of Jensen and Burris (1986) by Burgess and Lowe (1996). The re-interpretation suggested there may be an additional pathway from $\mathrm{N}_{2} \mathrm{O}$ to $\mathrm{NH}_{3}$ which does not involve $\mathrm{N}_{2}$ as an intermediary. Enzyme kinetics indicate a low affinity of $\mathrm{N}_{2} \mathrm{O}$ to nitrogenase. A $k_{m}$ value of $24 \mathrm{kPa}$ for purified component proteins from Klebsiella pneumoniae

Published by Copernicus Publications on behalf of the European Geosciences Union. 


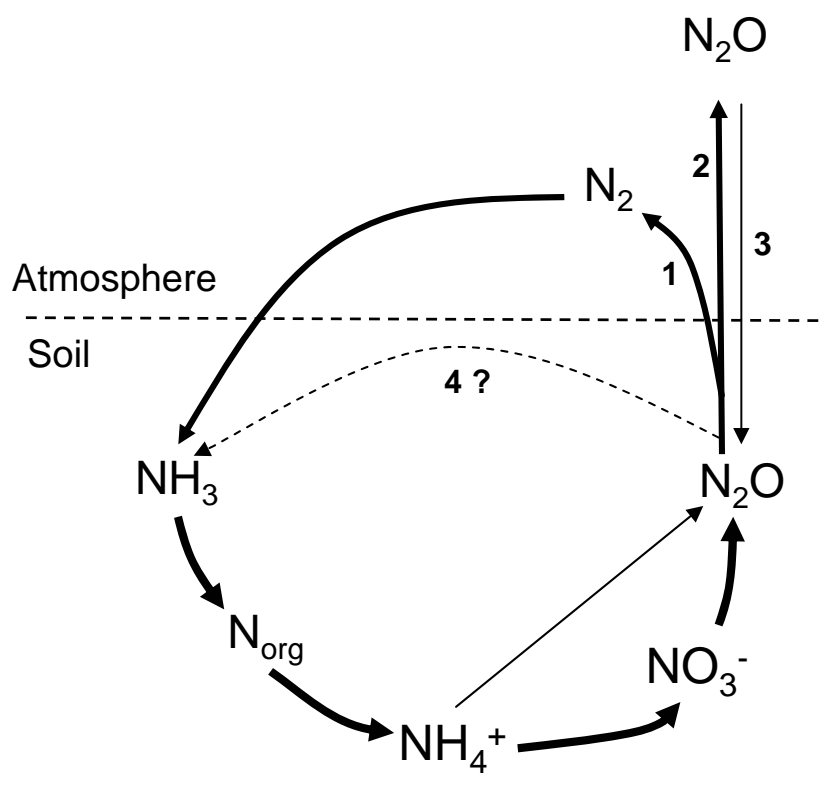

Fig. 1. Origin and possible fate of $\mathrm{N}_{2} \mathrm{O}$ in soil. (1) Complete denitrification to $\mathrm{N}_{2}$ before escape from the cell; (2) escape from cell; (3) re-entering a cell and subsequent reduction to $\mathrm{N}_{2}$, or (4) assimilatory reduction to $\mathrm{NH}_{3}$. The ecological relevance of pathway (4) in natural soil is unknown and the focus of this study.

has been determined by Jensen and Burris (1986). Yet, (apparent) substrate affinity can vary substantially between organisms and possibly methods. For $\mathrm{N}_{2} \mathrm{O}$ consumption by anoxic soil incubations and denitrifiers, for example, $k_{m}$ values differing by a factor of 2000 have been reported (Conrad, 1996). Even so, we would not expect nitrogenase to substantially contribute to $\mathrm{N}_{2} \mathrm{O}$ consumption within the range of naturally occurring $\mathrm{N}_{2} \mathrm{O}$ concentrations. Yet, other, unknown processes may account for some of the observed $\mathrm{N}_{2} \mathrm{O}$ consumption in soil. Discovery of new processes and responsible organisms continues to our days (e.g., Strous et al., 1999). Strong support for the possible existence of assimilatory reduction of $\mathrm{N}_{2} \mathrm{O}$ to $\mathrm{NH}_{3}$ comes from thermodynamical considerations. Shestakov and Shilov (2001) concluded after the theoretical study of model reactions involving $\mathrm{N}_{2} \mathrm{O}$ that a direct reduction of $\mathrm{N}_{2} \mathrm{O}$ to $\mathrm{NH}_{3}$ would be possible and thermodynamically advantageous to a reduction of $\mathrm{N}_{2}$. The dissociation energy for the $\mathrm{N}-\mathrm{N}$ bond in $\mathrm{N}_{2} \mathrm{O}$ is only half that of the $\mathrm{N}_{2}$ molecule (Herzberg, 1966). Our objective was to clarify whether such a reduction of $\mathrm{N}_{2} \mathrm{O}$ is an ecologically relevant process occurring in soil.

\section{Material and methods}

Samples were obtained from the upper $10 \mathrm{~cm}$ of soil at three locations in Switzerland and one location in SouthWest Germany. The first site, A, is located at ZurichReckenholz $\left(47^{\circ} 26^{\prime} \mathrm{N}, 8^{\circ} 32^{\prime} \mathrm{E}\right.$ at $491 \mathrm{~m}$ a.m.s.l.), the sec- ond site, $\mathrm{B}$, is located in central Switzerland $\left(47^{\circ} 17^{\prime} \mathrm{N}\right.$, $7^{\circ} 44^{\prime} \mathrm{E}$ at $450 \mathrm{~m}$ a.m.s.l.; for more details see Flechard et al. 2005). Both sites have soil types classified as cambisol and are experimental grassland sites of the Research Station ART (Agroscope Reckenholz-Tänikon), Switzerland. The third site, $\mathrm{C}$, is located close to Basel $\left(47^{\circ} 28^{\prime} \mathrm{N}, 7^{\circ} 42^{\prime} \mathrm{E}\right.$ at $476 \mathrm{~m}$ a.m.s.l.) in a mixed deciduous forest on pseudogley over limestone; and the fourth site, D, is an open pine (Pinus spp.) forest on a peat bog in the Black Forest located $70 \mathrm{~km}$ north of Basel $\left(47^{\circ} 52^{\prime} \mathrm{N}, 8^{\circ} 06^{\prime} \mathrm{E}\right.$ at $975 \mathrm{~m}$ a.m.s.l.).

The soils of these sites range in texture from sandy loam to clay loam and organic, in $\mathrm{pH}$ from 2.9 to 7.0 , in the $\mathrm{C}: \mathrm{N}$ ratio from 9.4 to 28.8 and in the soil moisture from 23.0 to $93.6 \%$ (Table 1). Fresh samples were broken into aggregates of $\leq 6.2 \mathrm{~mm}$ within $5 \mathrm{~h}$ after collection from the field sites and $200 \mathrm{~g}$ were placed into an incubation vessel (glass, $415 \mathrm{~cm}^{3}$ ) at $20^{\circ} \mathrm{C}$ for a $24 \mathrm{~h}$ pre-incubation period. To minimise entry of atmospheric $\mathrm{N}_{2}$ into the sample environment, we placed the incubation vessel during the entire experiment in an aluminium coated foil bag (volume about 21 ), which was continuously flushed with $\mathrm{He}\left(200 \mathrm{ml} \mathrm{min}^{-1}\right)$. During the incubation, the samples were exposed to a mixture of labelled $(98 \%){ }^{15} \mathrm{~N}_{2} \mathrm{O}(0.5-4 \mathrm{ppm})$ and $\mathrm{O}_{2}(0.2-0.4 \%)$ in $\mathrm{He}$ (with a purity of $99.9999 \%)$. Labelled ${ }^{15} \mathrm{~N}_{2} \mathrm{O}$ had been produced by the following thermal method. An amount of $0.1 \mathrm{~g}$ fully (98\%) labelled $\mathrm{NH}_{4} \mathrm{NO}_{3}$ (Cambridge Isotope Laboratories, Inc., Andover, USA) was gently heated with $5 \mathrm{ml} 6 \mathrm{M} \mathrm{HNO}_{3}$ and $0.05 \mathrm{~g} \mathrm{NaCl}$. The arising ${ }^{15} \mathrm{~N}_{2} \mathrm{O}$ was collected in a syringe. Later it was transferred with a stream of He into a $101 \mathrm{He}$ bottle filled to $1.1 \mathrm{bar}$ pressure and topped up with He to 6 bar. Close to $100 \%$ labelling of $\mathrm{N}_{2} \mathrm{O}$ with ${ }^{15} \mathrm{~N}$ was confirmed by mass spectrometry (T. Blunier, personal communication). In the incubation experiment, a gas stream of the labelled ${ }^{15} \mathrm{~N}_{2} \mathrm{O}, \mathrm{O}_{2}$ and $\mathrm{He}$ was mixed together and monitored by mass-flow controllers. It passed a humidifier and was divided into two equal streams with flow rates around $30 \mathrm{ml} \mathrm{min}^{-1}$. One of the gas streams passed through the incubation vessel containing the soil sample before entering a 6-port selection valve (Valco Instruments Co. Inc., Houston, Texas, USA). The second gas stream arrived directly at the selection valve. This valve selected alternating one of the gas streams and sent it through a Nafion dryer $\left(\mathrm{MD}^{\mathrm{TM}} \mathrm{Se}-\right.$ ries Gas dryer, Perma Pure LLC., Toms River, N.J., USA) to a $2 \mathrm{ml}$ sample loop on an injection valve (10-port selection valve, Valco Instruments Co. Inc., Houston, Texas, USA) for $5 \mathrm{~min}$, while the other gas stream was vented to the atmosphere. Concentrations of $\mathrm{N}_{2} \mathrm{O}$ were measured by GC-ECD (SRI8610C Gas Chromotograph; SRI Instruments Inc., Las Vegas, N.V., USA). By varying the concentration of $\mathrm{N}_{2} \mathrm{O}$ in the gas mixture, we were able to determine rates of gross production and gross consumption of $\mathrm{N}_{2} \mathrm{O}$ from a linear regression fitted through the measured net $\mathrm{N}_{2} \mathrm{O}$ fluxes against $\mathrm{N}_{2} \mathrm{O}$ concentrations (Vieten et al., 2007). The $\delta^{15} \mathrm{~N}$ of soil organic matter (SOM) was measured (on three or more sub-samples) before and after an 11 to 29 day incubation period (Table 1) 
Table 1. Summary of soil sample properties and the results of the incubation experiments with ${ }^{15} \mathrm{~N}$ labelled $\mathrm{N}_{2} \mathrm{O}$.

\begin{tabular}{lllll}
\hline Sample & $\mathrm{A}$ & $\mathrm{B}$ & $\mathrm{C}$ & $\mathrm{D}$ \\
\hline Ecosystem & Grassland & Grassland & Forest & Forest \\
Soil type & Cambisol & Cambisol & Pseudogley & Histosol \\
Texture & Sandy loam & Clay loam & Loam & Organic \\
$\mathrm{C}: \mathrm{N}$ ratio & 11.2 & 9.4 & 14.6 & 28.8 \\
$\mathrm{pH}$ in $0.01 \mathrm{M} \mathrm{CaCl}_{2}$ & 6.1 & 5.7 & 7.0 & 2.9 \\
Moisture [\%] & 23.0 & 33.9 & 33.3 & 93.6 \\
dry weight of sample [g] & 154 & 132.2 & 133.4 & 12.8 \\
Initial mass of ${ }^{15} \mathrm{~N}$ in sample [mg] & 1.02 & 1.55 & 1.91 & 0.82 \\
Duration of incubation [days] & 11 & 20 & 12 & 29 \\
${ }^{15} \mathrm{~N}_{2} \mathrm{O}$ offered to sample [mg $\left.{ }^{15} \mathrm{~N}\right]$ & 1.23 & 1.86 & 0.81 & 1.84 \\
${ }^{15} \mathrm{~N}_{2} \mathrm{O}$ consumed [mg $\left.{ }^{15} \mathrm{~N}\right]$ & 0.21 & 0.18 & 0.29 & 0.20 \\
Shift in $\delta^{15} \mathrm{~N}$ during incubation [] & 0.12 & -0.23 & -0.09 & 0.66 \\
\hline
\end{tabular}

on the Flash Elemental Analyser (Thermo Finnigan; Milano, Italy) connected to a CF-IR-MS (DELTA ${ }^{\text {plus } X P \text {; Thermo }}$ Finnigan MAT; Bremen, Germany).

\section{Results and discussions}

During the incubation period of 11 to 29 days, between 0.81 and $1.86 \mathrm{mg}$ of fully labelled ${ }^{15} \mathrm{~N}_{2} \mathrm{O}$ were flowing through each soil sample, containing a background of $0.82 \mathrm{mg}$ to $1.91 \mathrm{mg}$ of ${ }^{15} \mathrm{~N}$ in organic matter (Table 1). During this time, $0.18 \mathrm{mg}$ to $0.29 \mathrm{mg}$ of the offered ${ }^{15} \mathrm{~N}_{2} \mathrm{O}$ was consumed (Table 1). Figure 2 presents the fraction of consumed ${ }^{15} \mathrm{~N}_{2} \mathrm{O}-\mathrm{N}$ that might have been retained as part of the soil organic matter. This fraction was between $-0.20 \%( \pm 0.11 \%)$ and $0.27 \%$ $( \pm 0.19 \%)$ with an average across all four soils of $0.019 \%$ $( \pm 0.12 \%)$. None of the measured values were significantly different from zero $(p>0.05)$. Thus, we can consider them as measurement noise. Still, their presentation is useful insofar as it serves to illustrate the sensitivity of our method. This sensitivity was about one order of magnitude larger than that of the classical assay for $\mathrm{N}_{2}$ fixation by acetylene reduction, as for example described by Weaver and Danso (1994). This sensitivity was brought about by the long duration of the incubation, the large atom fraction of ${ }^{15} \mathrm{~N}$ in the consumed $\mathrm{N}_{2} \mathrm{O}(>0.98)$ and the high rates of $\mathrm{N}_{2} \mathrm{O}$ consumption by the soil samples. During the incubation period, an equivalent of $11.6 \%$ to $24.4 \%$ of ${ }^{15} \mathrm{~N}$ initially present in the soil samples was consumed as ${ }^{15} \mathrm{~N}_{2} \mathrm{O}$ (Table 1).

No significant $\mathrm{N}_{2} \mathrm{O}$ production by the soil samples themselves was detected during these experiments. Therefore ${ }^{15} \mathrm{~N}_{2} \mathrm{O}$ would have been the principal source for potential $\mathrm{N}_{2} \mathrm{O}$ assimilation. During our experiments, we incubated the soils with $\mathrm{He}$ (purity of $99.9999 \%$ ) plus small amounts of $\mathrm{O}_{2}$ and ${ }^{15} \mathrm{~N}_{2} \mathrm{O}$. Since we flushed the aluminium-coated foil bag that was around the incubation vessel continuously with $\mathrm{He}$, we reduced the potential influx of atmospheric $\mathrm{N}_{2}$ into

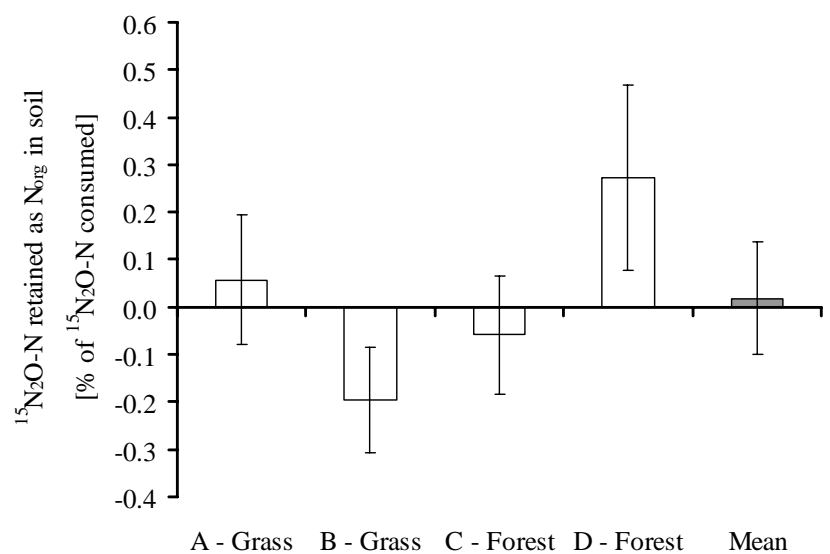

Fig. 2. Proportion of consumed ${ }^{15} \mathrm{~N}_{2} \mathrm{O}-\mathrm{N}$ that might have been retained in four soil samples. Error bars indicate \pm 1 standard error of the measurement as determined by the measurements of $\delta^{15} \mathrm{~N}$ in soil organic matter on replicate sub-samples before and after the incubation period. The proportion retained has been calculated as: Shift in $\delta^{15} \mathrm{~N}$ during incubation [\%o]/1000 [\%o] * initial mass of ${ }^{15} \mathrm{~N}$ in sample $[\mathrm{mg}] /{ }^{15} \mathrm{~N}_{2} \mathrm{O}$ consumed [mg] $* 100[\%]$.

the sample. We did not measure $\mathrm{N}_{2}$ concentrations in the sample air but estimate that it has been in the order of ppm rather than per mil. Compared to the natural environment, the competitive advantage of $\mathrm{N}_{2} \mathrm{O}$ (here: $0.5-4 \mathrm{ppm}$ ) relative to $\mathrm{N}_{2}$ to be assimilated had been shifted by orders of magnitude in favour of $\mathrm{N}_{2} \mathrm{O}$. Thus, the likelihood for soil organisms to reduce $\mathrm{N}_{2} \mathrm{O}$ instead of $\mathrm{N}_{2}$ to $\mathrm{NH}_{3}$ was substantially increased. Maybe, we should underline here that it was not our objective to measure nitrogenase activity but to find out whether some proportion of $\mathrm{N}_{2} \mathrm{O}$ consumed in soil is assimilated, by whatever reduction pathway possible. Our method of choice $\left({ }^{15} \mathrm{~N}_{2} \mathrm{O}\right.$ labelling) would be unable to tell us anything specific about the nature of the pathway. We still chose 
this method because detection of ${ }^{15} \mathrm{~N}$ in tissues of biological systems exposed to labelled $\mathrm{N}$ gas is the only direct, unequivocal method for demonstrating that its assimilation occurred (Weaver and Danso, 1994).

The negative result regarding $\mathrm{N}_{2} \mathrm{O}$ assimilation is unexpected, considering the observed large rates of $\mathrm{N}_{2} \mathrm{O}$ consumption, the thermodynamical advantage of $\mathrm{N}_{2} \mathrm{O}$ over $\mathrm{N}_{2}$ as a substrate for the production of $\mathrm{NH}_{3}$ (Shestakov and Shilov, 2001), and the evidence of direct $\mathrm{N}_{2} \mathrm{O}$ to $\mathrm{NH}_{3}$ reduction as a biological process (Yamazaki et al., 1987) albeit only for a low affinity enzyme (Jensen and Burris, 1986) so far. One would expect natural selection to have favoured organisms assimilating $\mathrm{N}_{2} \mathrm{O}$ rather than $\mathrm{N}_{2}$. We can not completely rule out that $\mathrm{N}_{2} \mathrm{O}$ assimilation may have some ecological importance, at least in $\mathrm{N}$ limited soils. Still, our results strongly indicate that in environments similar to those studied here, $\mathrm{N}_{2} \mathrm{O}$ assimilation is an ecologically irrelevant pathway in $\mathrm{N}_{2} \mathrm{O}$ consumption by soil. Thus, the general assumption that $\mathrm{N}_{2} \mathrm{O}$ is exclusively consumed by dissimilatory reduction to $\mathrm{N}_{2}$ (i.e. complete denitrification) almost certainly applies in these environments.

Acknowledgements. We thank Thomas Blunier from the Institute of Climate and Environmental Physics of the University of Bern for analysing our labelled ${ }^{15} \mathrm{~N}_{2} \mathrm{O}$. This study was supported by the Swiss State Secretariat for Education and Research through grant Nr. C04.0254 to COST Action 856 and the Swiss National Science Foundation.

\section{References}

Burgess, B. K. and Lowe, D. J.: Mechanism of molybdenum nitrogenase, Chem. Rev., 96, 2983-3011, 1996.

Chapuis-Lardy, L., Wrage, N., Metay, A., Chottes, J. L., and Bernouxs, M.: Soils, a sink for $\mathrm{N}_{2} \mathrm{O}$ ? A review, Global Change Biol., 13, 1-17, 2007.

Clough, T. J., Sherlock, R. R., and Rolston, D. E.: A review of the movement and fate of $\mathrm{N}_{2} \mathrm{O}$ in the subsoil, Nutr. Cycl. Agroecosys., 72, 3-11, 2005.

Conrad, R.: Soil microorganisms as controllers of atmospheric trace gases $\left(\mathrm{H}_{2}, \mathrm{CO}, \mathrm{CH}_{4}, \mathrm{OCS}, \mathrm{N}_{2} \mathrm{O}\right.$, and $\left.\mathrm{NO}\right)$, Microbiol. Rev., 60 , 609-640, 1996.

Firestone, M. K., Firestone, R. B., and Tiedje, J. M.: Nitrous Oxide from Soil Denitrification: Factors Controlling Its Biological Production, Science, 208, 749-751, 1980.
Flechard, C. R., Neftel, A., Jocher, M., Amman, C., and Fuhrer, J.: Bi-directional soil/atmosphere $\mathrm{N}_{2} \mathrm{O}$ exchange over two mown grassland systems with contrasting management practices, Global Change Biol., 11, 2114-2127, 2005.

Hardy, R. W. F. and Knight, E.: Reduction of $\mathrm{N}_{2} \mathrm{O}$ by biological $\mathrm{N}_{2}-$ fixing systems, Biochem. Bioph. Res. Co., 23, 409-414, 1966.

Herzberg, G.: Molecular spectra and molecular structure: Electronic spectra and electronic structure of polyatomic molecule, 3, Van Nostrand, Reinhold, New York, 778 pp., 1966.

Hoch, G. E., Schneider, K. C., and Burris, R. H.: Hydrogen evolution and exchange, and conversion of $\mathrm{N} 2 \mathrm{O}$ to $\mathrm{N} 2$ by soybean root nodules, Biochimica et Biophysica Acta, 37, 273-279, 1960.

IPCC: 2006 IPCC Guidelines for National Greenhouse Gas Inventories, IGES, Japan, 2006.

Jensen, B. B. and Burris, R. H.: $\mathrm{N}_{2} \mathrm{O}$ as a substrate and as a competitive inhibitor of nitrogenase, Biochemistry, 25, 1083-1088, 1986.

Mozen, M. M. and Burris, R. H.: The incorporation of ${ }^{15} \mathrm{~N}$-labelled nitrous oxide by nitrogen fixing agents, Biochimica et Biophysica Acta, 14, 577-578, 1954.

Neftel, A., Blatter, A., and Schmid, M.: An experimental determination of the scale length of $\mathrm{N}_{2} \mathrm{O}$ in the soil of a grassland, $\mathrm{J}$. Geophys. Res., 105, 12 095-12 103, 2000.

Ostrom, N. E., Pitt, A., Sutka, R., Ostrom, P. H., Grandy, A. S., Huizinga, K. M., and Roberston, G. P.: Isotopologue effects during $\mathrm{N}_{2} \mathrm{O}$ reduction in soils and in pure cultures of denitrifiers, J. Geophys. Res., 112, G02005, doi:10.1029/2006JG000287, 2007.

Shestakov, A. F. and Shilov, A. E.: On the coupled oxidationreduction mechanism of molecular nitrogen fixation, Russian Chemical Bulletin, International Edition, 50, 2054-2059, 2001.

Strous, M., Fuerst, J. A., Kramer, E. H. M., Logemann, S., Muyzer, G., van de Pas-Schoonen, K. T., Webb, R., Kuenen, J. G., and Jetten, M. S. M.: Missing lithotroph identified as new planctomycete, Nature, 400, 446-449, 1999.

Vieten, B., Blunier, T., Neftel, A., Alewell, C., and Conen, F.: Fractionation factors for stable isotopes of $\mathrm{N}$ and $\mathrm{O}$ during $\mathrm{N}_{2} \mathrm{O}$ reduction in soil depend on reaction rate constant, Rapid Commun. Mass Sp., 21, 846-850, 2007.

Weaver, R. W. and Danso, S. K. A.: Dinitrogen fixation: Methods of soil Analysis, Part 2. Microbiological and Biochemical Properties, Bigham, J. M., Soil Science Society of America, Inc., Madison, 1019-1045, 1994.

Yamazaki, T., Yoshida, N., Wada, E., and Matsuo, S.: $\mathrm{N}_{2} \mathrm{O}$ reduction by Azotobacter vinelandii with emphasis on kinetic nitrogen isotope effects, Plant Cell Physiol., 28, 263-271, 1987.

Zumft, W.: Cell biology and molecular basis of denitrification, Microbiology and Moecular Biology Reviews, 61, 533-616, 1997. 